\title{
Recognising Recognition in Climate Justice
}

\section{Tor A. Benjaminsen, Hanne Svarstad and Iselin Shaw of Tordarroch}

\begin{abstract}
We argue that in order to achieve climate justice, recognition needs to be given more attention in climate research, discourse, and policies. Through the analysis of three examples, we identify formal and discursive recognition as central types of recognition in climate issues, and we show how powerful actors exercise their power in ways that cause climate injustice through formal and discursive misrecognition of poor and vulnerable groups. The three examples discussed are climate mitigation through forest conservation (REDD), the Great Green Wall project in Sahel, and the narrative about climate change as a contributing factor to the Syrian war.
\end{abstract}

Keywords climate justice, recognition, REDD+, Great Green Wall, afforestation, Tanzania, Sahel, Syria, climate-conflict-migration nexus.

\section{Introduction}

Recognition has so far received modest attention in leading discourses and policies related to climate change mitigation including in the academic literature. In the 1990s, a radical justice tradition emerged in political philosophy inspired by recognition theory rooted in the ideas of Enlightenment philosophers such as Kant, Fichte, and Hegel. This new approach to justice theory had mainly a focus on distributive justice and recognition, and with procedural justice later added as a third element (Honneth 1995; Fraser 1999; Fraser and Honneth 2003; Fraser 2009).

Influenced by this approach to justice, Schlosberg (2003) introduced the three elements as key aspects of environmental justice, which has become a dominant approach to the field (Svarstad and Benjaminsen 2020). Previously, Rawls' focus on distributive justice (Rawls 1971) had been an important source of 
inspiration for environmental justice scholars in addition to more critical approaches (e.g. Pulido 1996; Pellow 2002).

During the last few years, particular attention has been given to dimensions of recognition in environmental justice (e.g. Martin et al. 2016; Bétrisey, Bastiaensen and Mager 2018; Fraser 2018). However, as a thematic sub-field of environmental justice, climate justice scholarship has still devoted modest attention to recognition, despite a few important exceptions (e.g. Hordequin 2016; Kortetmäki 2016; Chu and Michael 2018; Preston and Carr 2018). The lack of attention to recognition in climate justice can perhaps be explained by the fact that it may appear as a more complex and less straightforward form of justice than distribution (who gets what) and procedure (who decides and how), with both its formal and discursive aspects as discussed further in Section 2.

Climate justice research, politics, and practice have primarily focused on unfair distribution of consequences of climate change or of climate mitigation actions as well as on who is involved in decision-making on climate change action. Such distributive and procedural climate justice has both a temporal and a spatial side. While temporal climate justice emphasises justice for coming generations, spatial climate justice concerns the distribution of burdens among people today, and with a particular concern for people who live in poverty in the global South (Svarstad 2021).

We argue in this article that recognition should also be a key element of justice in climate justice. Besides being an important aim for justice in itself, recognition is necessary in order to obtain distributive and procedural justice. Actors affected by climate change or mitigation measures should be recognised as participants in formal decision-making, and their situations, perspectives, and participations should also be recognised as crucial in the discourses framing climate policies and laws.

We argue that lack of both formal and discursive recognition constitutes injustice. Such exclusion also disguises causation and off-tracks from more effective solutions. A major way misrecognition takes place in climate mitigation policies is through the elaboration of leading discourses on climate mitigation measures in a non-inclusive fashion. Leading discourses are social constructions, which also influence policies and practices. Some groups are misrecognised through presentations that deviate substantially from their own perspectives. At the same time, powerful actors influence discourses and related policies and practices according to their own interests.

While marginalised and subaltern groups often suffer from misrecognition including being ignored, the flip side of this process occurs when powerful interests manage to render their own power invisible in leading climate discourses from which they benefit. Hence, justice and injustice are closely associated 
with power. While some groups control power resources to follow their interests, others do not, and therefore experience injustice (Benjaminsen and Svarstad 2021).

We substantiate these arguments through the discussion of three examples - the first two are about large-scale climate mitigation projects, and the latter relates more to broader discourse formation.

The first example is about carbon removal through interventions such as reducing emissions from deforestation and forest degradation (REDD) in developing countries. This is an approach that is claimed by its supporters to provide cost-effective climate mitigation, but such estimations neglect the livelihood costs of forest-adjacent communities that lose access to forest resources. Misrecognition of subaltern livelihoods through REDD should be seen in association with the exercise of discursive power by fossil-fuel interests in the global North.

The second example is the Great Green Wall project in the Sahel, which is based on a top-down technical approach, initiated by a few African presidents and funded by Western and United Nations (UN) agencies. This project is presented as a solution both to stop desertification, to mitigate climate change, and to reduce insecurity and conflicts in the Sahel. While providing a green image to its donors, the project neglects the needs of Sahelian pastoralists who are most severely affected by its implementation.

The third example is taken from the debate over whether the Syria conflict was partly triggered by climate-induced drought. Proponents of this argument refer to a narrative that views drought as a 'threat multiplier', and the Syrian war as a typical example of a positive correlation between climate change and conflict. Interviews with displaced Syrians reveal, however, a mismatch between this narrative and their own. To them, claiming that climate change played a significant role in triggering their revolution and later, war, obscures and misrecognises more important causes and undermines their agency as political actors.

Hence, we argue first for the need to focus on recognition of specific groups that are affected by climate discourses and associated policies, and second, we focus on how powerful actors and institutions ignore or misrecognise these groups when producing discourses and policies. Finally, besides the ongoing injustice experienced by affected groups today, climate injustice may also affect future generations by deviating from urgent action to reduce climate emissions.

\section{Recognition as climate justice}

The conception of recognition in justice theory has in particular been inspired by the work of political philosophers Nancy Fraser and Axel Honneth (Fraser and Honneth 2003). Fraser (2000) 
connects recognition to social status and sees misrecognition as the institutionalisation of social subordination. Such misrecognition may take place in different ways, for example, through cultural domination, non-recognition (or lack of recognition), or disrespect. Misrecognition may be connected to social categories such as gender, race, religion, or ethnicity.

Fraser sees recognition and distribution as two parallel dimensions of justice. This is in disagreement with Honneth who argues that recognition is the fundamental and overarching category of justice, which means that questions of distribution and redistribution are derived from recognition (Fraser and Honneth 2003). However, to Fraser, 'not all maldistribution is a by-product of misrecognition' (Fraser and Honneth 2003: 35). The injustice and maldistribution produced by speculative capitalism may not necessarily be linked to misrecognition, she argues.'

We agree that sometimes injustice has other causes than social status and recognition. However, in policy formulation, such as in climate policies, we would argue that recognition may tend to constitute an overarching dimension of justice.

Without some form of recognition, it is unlikely that a group of people will benefit from distributive or procedural justice. Recognition concerns who is given respect (or not) and whose interests, values, and views are recognised and taken into account. In the context of climate change, recognition may be seen as referring in particular to whose knowledge, interests, priorities, and livelihoods are considered valuable in social constructions such as leading discourses and narratives, as well as in politics and practice.

While Fraser tends to focus on legal or formal recognition primarily through state institutions, Honneth conceives recognition as containing two dimensions - legal recognition in terms of formal rights and intersubjective recognition consisting of solidarity and love (Fraser 2018). In climate discourse, policy, and practice, misrecognition may be linked to both lack of formal rights as well as lack of solidarity with marginalised peoples among powerful actors and policymakers.

In discussing misrecognition, Fraser (2009) develops further Hannah Arendt's concept of 'misframing' (Arendt 1973). This concept refers to who has the right to have rights and the fact that some people become non-persons with respect to justice. While those who suffer may become objects of charity, they remain without any formal rights to justice. Such misframings may shield powerful states and transnational companies from the reach of justice, and it may be seen as the defining injustice of a globalising age, according to Fraser (2009). This politics of framing, which refers to who counts as an object of justice, makes invisible both the subaltern groups who suffer from injustice as 
well as the power of countries, institutions, or companies who are at the source of this injustice.

However, while both Arendt and Fraser focus on formal justice, we think this notion of misframing can be extended also to intersubjective justice. Marginalised people are made invisible not only as legal objects of justice, but also in leading discourses and practices as actors in their own right. Their interests, priorities, and livelihoods are neglected. They are therefore not only outside the realm of formal justice, but are also neglected and misrecognised discursively, which reflects a non-formal type of misrecognition that may be seen as lack of solidarity.

In the rest of this article, we discuss three examples through the lens of not only formal (mis)recognition, but also intersubjective forms expressed through discursive (mis)recognition.

\section{Reducing emissions from deforestation and forest degradation (REDD)}

REDD emerged in the 2000s. By 2015-16, countries mainly in the global North had spent more than US\$10bn on this programme (Angelsen et al. 2017), and with implementation in at least 69 countries in the global South (Asiyanbi and Lund 2020). A plus sign has been added (REDD+) to indicate that apart from targets of climate mitigation, the programme seeks to include community benefits. Norway is by far a leading funder as well as a central promoter of REDD+, and later in this section we present an example of a Norwegian-funded REDD+ intervention in Tanzania.

The introduction of REDD+ was based on claims of cost-effective climate mitigation. For Norway, REDD+ might be seen as cost-effective in comparison to the cost of reducing climate emissions by, for instance, leaving Norway's petroleum resources in the ground. However, continued emissions from fossil fuel can be seen as contrary to climate justice in time and space when they take place in ways that are negative to people who live in poverty, such as when the livelihoods of forest-adjacent communities are undermined without proper compensation (Svarstad 2021).

Interventions financed by REDD+ have taken place and are still going on covering vast areas in the global South, affecting an unknown number of local communities and people. However, research reveals serious problems with this programme (see, for example, Asiyanbi 2016; Asiyanbi and Lund 2020; Chomba et al. 2016; Krause, Collen and Nicholas 2013; Pasgaard and Chea 2013; Svarstad and Benjaminsen 2017).

We here concentrate on findings of a case studied over several years that examined the social implications of a REDD+ pilot project in Tanzania (Svarstad and Benjaminsen 2017). At project start in 2010, the area was characterised by widespread poverty 
amongst 62,000 agro-pastoral smallholders in 21 villages surrounding a forest ridge. Twenty-eight per cent of the inhabitants were estimated to live in deep poverty with an income of less than one dollar a day, and a large part of the rest of the population was also considered to be poor (Mung'ong'o et al. 2011).

The project introduced a strict regime of forest conservation, with limitations in the use of forest resources for daily livelihood means such as firewood and grazing. The main purpose was to reserve the forest for climate mitigation. Funding came from the Foreign Ministry of Norway during 2010-14, and the project was facilitated by the environmental non-governmental organisation (NGO) African Wildlife Foundation (AWF). During the project period, both donor and facilitator presented this project as particularly successful and in line with a win-win scenario involving climate mitigation and conservation as well as benefits that not only compensated villagers for the forest closure, but also contributed to poverty reduction (Royal Norwegian Embassy 2012, 2014).

Counter to this, Svarstad and Benjaminsen (2017) found that three overlapping groups were adversely affected by the restrictions that the project made on forest use. First, people living close to the forest and without alternative forests nearby tended to be more seriously affected than others. Second, villagers with relatively small farms or without farmland at all were more affected than others. This is because many villagers who lack sufficient farmland depend more on forest resources to sustain a living, for instance, by charcoal production. Third, women tended to be more affected than men, because of their roles in the gendered division of labour, and particularly with collecting firewood for domestic purposes.

The planned benefits from the project can be divided into long-term and short-term benefits (Norwegian Ministry of Foreign Affairs and AWF 2009). The long-term benefits should come from selling carbon credits in international carbon markets. However, after the project was finished, AWF finally admitted that the efforts to obtain certification for this project had failed.

The short-term benefits were planned to come from support to alternative livelihoods such as intensifying agricultural production, planting trees, and producing 'sustainable charcoal' on the smallholders' own plots. Despite repeated presentations of the great success of the project components and particularly of enhancing agricultural output, these claims were found to be unsubstantiated (Svarstad and Benjaminsen 2017).

All in all, this is a case of REDD+ that was celebrated by both the donor and the facilitating NGO as a great win-win, although independent and critical research reveals a clear case of climate injustice. People living in poverty were negatively affected, and 
these are people who probably have some of the lowest climate footprints in the world. The injustice was brought on them by the Government of Norway, a country with high climate emissions directly, as well as indirectly from benefiting economically from fossil-fuel export.

How was this possible? This outcome can be explained by the lack of two types of recognition. First, there is a lack of formal recognition. Actors behind REDD+ often refer to safeguards established by the UN to avoid the negative consequences of REDD+ (UN-REDD Programme 2012). However, these are vague and unbinding formulations and do not provide vulnerable people with formal rights to avoid negative impacts.

Second, the livelihoods and interests of people who are negatively affected by REDD+ are not discursively recognised and made visible in the sense that there is hardly any knowledge about them in donor countries, such as Norway. Therefore, the victims of climate injustice through REDD+ are not heard or seen, and instead their misrecognition in the leading discourse in Norway about REDD+ as a win-win is seldom contested. Thus, there are hardly any voices in a country such as Norway to speak up for victims of REDD+. There are several reasons for this. One reason is that nearly all political parties as well as environmental and solidarity organisations in Norway supported the idea of a large Norwegian REDD+ programme from the beginning, and they have later found it to be in their self-interest to refrain from criticising REDD+. Today, there is a political consensus to continue the Norwegian REDD+ programme until at least 2030. Other reasons are the lack of independent and critical research on Norwegian-funded initiatives as well as lack of critical media coverage.

Thus, the Norwegian government handles REDD+ in a technical manner along with a simple win-win narrative and can continue to do so without much attention. The silent continuation of REDD+ is also convenient for powerful interests behind the petroleum industry and other high emission activities, because REDD+ is presented as a major climate measure without the need for costly changes within Norway.

\section{The Great Green Wall in the Sahel}

The Great Green Wall (GGW) is planned as a $15 \mathrm{~km}$-wide wall of trees over a stretch of $8,000 \mathrm{~km}$, from Senegal to Djibouti. The project was conceived in 2005 by a group of African heads of state including, in particular, the former president of Senegal, Abdoulaye Wade, former president of Nigeria, Olesegun Obasanjo, and former leader of Libya, Mouammar Gaddafi. It was formally approved by the African Union as a Pan-African project in 2007, and it has later received financial support from the Food and Agriculture Organization of the United Nations, World Bank, Global Environment Facility, European Union, and International 
Union for Conservation of Nature (UNCCD 2020). At the climate summit in Paris in December 2015, donors pledged a total of US\$4bn to the project, but by 2020, the project had received merely US\$870m of this promised funding (UNCCD 2020).

The aims of the GGW are to restore 100m hectares of degraded land, create $10 \mathrm{~m}$ jobs, and sequestrate $250 \mathrm{~m}$ tonnes of carbon by 2030. It is believed that these results will furthermore bring down recruitment to jihadist insurgency and reduce migration from the Sahel to Europe (Great Green Wall 2021).

Due to the project being championed by former president Wade, Senegal is without doubt the leading country in implementing the GGW where most of the land restoration has taken place (leading some to name it 'the great Senegalese wall'). So far, there has been minimal project activity in the other Sahelian countries (Magrin and Mugelé 2020). An evaluation initiated by the United Nations Convention to Combat Desertification (UNCCD) concluded that by 2020, only 4 per cent of the planned area had been afforested. This meagre result is due to a general lack of enthusiasm among those Sahelian governments occupied with more pressing issues, as well as among donors who see the project as too risky amidst the security situation in the region (Mugelé 2018; Magrin and Mugelé 2020).

The fact that the Sahel has been greening following increased rainfall the last few decades (see, for example, Benjaminsen and Hiernaux 2019) may have led to additional hesitation among donors. Moreover, survival rates of tree seedlings in the Sahel are low unless they are actively watered by hand. According to Yeo (2018), the survival rate in the GGW plantations in Senegal has been 45 per cent following intensive watering and protection of the seedlings.

The documented greening is also said to have recently changed the approach of the project from tree planting 'to become a mosaic of resilient land use systems with the capacity to adapt to uncertainty and climatic extremes' (UNCCD 2020: 29). However, this change of approach is not apparent in the project's self-presentation on its website, which is still focused on creating an $8,000 \mathrm{~km}$ wall of trees to stop the southward movement of the Sahara and, through this afforestation, to sequestrate a large amount of carbon.

The project activities have so far been dominated by a technical and top-down approach focused on tree planting. The project also suffers from lacking local involvement and participation (Mugelé 2018; Magrin and Mugelé 2020). Since the project is focused on the zone between $100 \mathrm{~mm}$ and $400 \mathrm{~mm}$ of annual rainfall, which is marginal for dryland farming, the local population consists primarily of pastoralists. 
Pastoralism has, however, not been taken into account in the design, planning, and implementation of the GGW (Mugelé 2018). In the Ferlo region in Senegal, where a large proportion of project activities have taken place, and where there is a centuries' long history of pastoral use, the pastoral dependence on access to land is not only neglected by the project, but pastoralism is also seen as an obstacle to the afforestation that project success is measured by. Through totally ignoring the needs of pastoralists and their livestock, the GGW exacerbates existing misrecognition of pastoralists in the form of lack of both formal and discursive recognition.

First, this misrecognition manifests in the blocking of pastoral mobility through enclosures of afforested areas. Second, it leads to loss of grazing areas that the pastoral system depends on, and third, the afforested areas and vegetable production within these areas compete with livestock for water. Ironically, this means that the GGW results in natural resource scarcity for the local population in the Ferlo, the Fulani pastoralists (Mugelé 2018).

The top-down approach of the project is also reinforced by the fact that it is implemented by the Water and Forest Department (Le Service des Eaux et Forêts), which is an old colonial institution with a para-military tradition of being an armed forest police (Benjaminsen 2000; Ribot 2001). In the central project area in the Ferlo region, there are eight state forest agents. None of them are from the region and none of them are Fulani (Mugelé 2018). These foresters are given the task of producing success measured by the number of trees planted and the area afforested (Mugelé 2018).

Traditional leaders and the elected leaders of local communes are also largely neglected by the project. They are not consulted and are merely told to comply with the decisions made by the project foresters pertaining, for instance, to the location of areas to be afforested. In addition, the foresters give local people fines for illegal use of tree products and when livestock manage to enter afforestation areas (Mugelé 2018). This is possible because the state formally owns all rural land in the Sahel (except individually titled land which is only a small percentage) (Benjaminsen et al. 2009), and pastoral custom is generally not recognised by state legislation or policies (Thébaud and Batterbury 2001). Forest legislation is strict with few local rights of access to forest products and with fines for infraction of rules. This has given state foresters considerable power compared to local populations (Benjaminsen 2000; Ribot 2001; Gautier et al. 2013).

This top-down and technical approach to forest management has a history dating back to the 1930s in the Sahel (Benjaminsen 2000), and rather than reducing conflicts, it risks further increasing tensions between pastoralists and state institutions. This tension is behind the recruitment of pastoralists to armed groups labelled 
'jihadist' (Benjaminsen and Ba 2019, 2021) and may therefore in the long run contribute to the opposite result of what the project intends.

The misrecognition of Sahelian pastoralists following this project as well as generally, is both formal in terms of lack of rights as well as discursive. The GGW is, to a large extent, conceived as a climate mitigation project, which led to massive donor interest at the Paris Climate Conference. The resulting misframing has made the victims of the initiative invisible; for instance, on the website of the GGW and in other project presentations.

When there is such straightforward misrecognition of the local population, in this case pastoralists in the Sahel, there is a clear risk that climate mitigation may lead not only to a failed climate project, but also to adverse results such as increased local natural resource scarcity and increased resistance to the state, which might ultimately exacerbate conflict levels.

\section{Climate as a conflict trigger in Syria?}

Another case of climate misrecognition is found in the Syriaclimate-conflict thesis. Since 2012, a narrative arguing that the war in Syria was partly climate induced, has journeyed from a handful of academic studies to grey literature and popular media. This has made the Syrian conflict one of the primary contemporary examples of climate-conflict narratives (Daoudy 2020). The main tenets of the Syria-climate-conflict thesis are that anthropogenic drought drove agricultural collapse and mass migration from Syria's northeast Jazira region, eventually leading to civil unrest in the urban centres that received migrants from the drought. Proponents of the thesis argue that the Syria case shows how climate change threatens to exacerbate socioeconomic conditions in fragile states to the extent that it increases the likelihood of conflict in certain contexts. None of the thesis' proponents argue that environmental factors alone triggered Syria's war, but at the very least, that they played an important role.

During the run-up to the 2015 Paris Climate Conference, mainly three peer-reviewed articles (Gleick 2014; Kelley et al. 2015; Werrell, Femia and Sternberg 2015) provided the empirical evidence for the thesis (Selby et al. 2017). The media and public figures picked up these three articles, fuelling leading discourse on what conflictual scenarios might await in a warmer world, with Syria as its empirical backing. Obama, Prince Charles, and Ban $\mathrm{Ki}$-moon are a select few of those who have voiced their support of the theory that climate change played a significant role in triggering the Syrian war (Selby 2018). This is the case, despite numerous studies critical of the thesis' underpinning evidence (e.g. Selby et al. 2017), its potential to underplay more important conflict triggers (e.g. de Châtel 2014), and narrow definition of environmental security (e.g. Daoudy 2020). 
Within the set of three studies supporting the Syria-climateconflict thesis, there is only a single mention of testimony from Syrians (Selby et al. 2017). The quote (in Kelley et al. 2015) from a displaced Syrian farmer is taken from a piece by New York Times journalist Thomas Friedman. For years, the Syria-climate-conflict thesis gained traction in public discourse with very scant input from the people who experienced the war and its consequences first hand.

Selby et al. (2017) raised this concern in a debate over the climate-conflict link in Syria that took place in Political Geography. Peter Gleick, water scholar and proponent of the thesis, responded to the critique by stating that interviews with displaced Syrians are 'interesting, but have no validity scientifically' (Gleick 2017: 249). Shaw of Tordarroch (2021) challenged this viewpoint by arguing the empirical value of qualitative inputs and not least, the importance of recognition in debates over proposed climate-conflict links. Her study concentrated on Syrian reactions, experiences, and perceptions surrounding the climate-conflict nexus and its application to the Syrian war.

A total of 79 Syrian participants took part across four qualitative focus group discussions and 15 semi-structured interviews. The study was conducted in the midst of the Covid-19 pandemic, thus all data collection sessions were carried out on the Zoom video conferencing platform, with all interview guides approved by the Norwegian Centre for Research Data. Sixty of the participants were refugees living in Turkish Sanliurfa, Gaziantep, and Kilis. Four were internally displaced persons living in the Syrian city of Jarabulus and the remaining 15 participants had been displaced from Syria and were now living in Norway. The entire sample lived in Syria between at least 2005 and 2011, and all considered themselves Syrian although a small number of participants were originally Palestinian (four) and Kurdish (two).

The data collection sessions were initiated by an unbiased explanation of the Syria-climate-conflict thesis by the interviewer, in an intelligible fashion that was not overly academic. The intent throughout the study was for the researcher to remain open to any potential findings.

Overall, Syrian participants were strongly disagreeable to the thesis and in several cases took offence to the suggestion that their revolution and war had a natural cause (Shaw of Tordarroch 2021). To them, the Syria-climate-conflict thesis fails to acknowledge the long-enduring plights of many Syrians, and that the events that unravelled in 2011 were driven by the popular desire to bring freedom, democracy, and reformation to Syria.

A majority of participants acknowledged the presence of drought and internal migration in Syria, but none associated these 
phenomena with the Syrian conflict. In fact, most supported a reverse sequence of the climate-conflict nexus, relaying concern over climatic effects of conflict rather than the other way around. The thesis was, in the view of several participants, an embodiment of the West's current preoccupation with climate change rather than an attempt to explain the war's causes or seek out a remedy for it.

The study found that Syrian participants express feeling persistent discursive misrecognition in the leading discourse about the Syrian conflict. As the previously quoted statement by Gleick illustrates, Syrian voices are not only excluded in the debate, but are also disregarded on the basis of not being seen as scientifically valuable. Such misrecognition constitutes a form of disrespect and lack of solidarity in which Syrian experiences, views, and interests are not considered knowledge on a par with Western or scientific knowledge. In this case, the misrecognised are not directly affected by climate or mitigation policies, but rather by dominating discourse in which climate is centre-stage.

Syrians in this study felt angered by the persistent focus on conflict triggers ten years on from the conflict's inception, instead of navigating policy towards instilling peace. In their view, the climate-conflict discourse on Syria presents a form of misrecognition by closing them out of the conversation and promoting the values, interests, and worldviews of powerful actors such as the West or Assad regime, rather than the millions of Syrians whose lives are eternally affected by the still ongoing war in Syria.

\section{Conclusions}

We argue in this article that recognition should be given more attention as an aspect of climate justice, and that misrecognition is a key source of climate injustice. Discussing three examples, we distinguish between formal and discursive (mis)recognition.

Formal recognition of affected people exists if policy or laws protect their rights to maintain basic needs and livelihoods, following the implementation of climate mitigation measures. In the case of REDD+, we showed how the UN have established safeguards to avoid negative consequences of REDD+, but these are not strong enough to protect poor and vulnerable people from the negative impacts of REDD+ interventions. Similarly, the GGW in the Sahel is implemented without involving the affected pastoralists. This project is also managed by an institution with a history of top-down approaches dating back to colonial times. In this institutional context, pastoralists have been portrayed as destroyers of the environment and have not been granted any formal land-use rights.

Leading discourses and narratives influence policies and practices. There is discursive recognition if a leading discourse 
or narrative takes account of the interests and livelihoods of the communities or peoples that will be affected by an initiative, and the presentation is in line with the senses of justice of these groups (Svarstad and Benjaminsen 2020). In the REDD+ case in Tanzania, a win-win narrative was produced by the actors behind the intervention, despite poor and vulnerable people being affected negatively. A win-win discourse on REDD+ remains hegemonic in policymaking, although an increasing body of research demonstrates how the programme has adverse effects on communities living in or close to forests and their livelihoods.

In a similar vein, pastoralists in the Sahel remain discursively invisible; for instance, on the website of the GGW and in other project presentations. The discursive and financial power of UN organisations, the World Bank and the European Union produces a framing about fighting desertification and reducing out-migration and violent conflicts in the Sahel through tree planting, which lacks any sound support in research or in the realities on the ground.

Misframing in climate change discourses disguises the interests of powerful actors and shields them from any accountability. In addition, the interests, agency, and livelihoods of subaltern groups are made invisible. Not only do they become non-persons in terms of formal justice, but also in discourse and practice they are disregarded as actors in their own right. They miss out on benefiting from legal justice, but also as they remain invisible, they are not subject to solidarity as a form of intersubjective recognition.

This rendering invisible is evident in all three cases discussed including the portrayal of the Syrian war as partly triggered by climate change. The displaced Syrians interviewed were largely unaware of this discursive misrecognition. They expressed the opinion that the leading discourse on the conflict departs from their own views and experience. Syrian voices have largely been neglected in the Syria-climate-conflict debate, despite their indisputable insight into why Syria descended into war, and their stake in how the rest of the world discursively understands the conflict. The environment-centric explanation of the Syrian war presented in the leading discourse impedes accurate and nuanced analyses, specifying responsibility for past and future action and opportunities to elaborate peaceful solutions.

Through the three examples, this article has shown how poor and vulnerable groups face climate injustice due to misrecognition. This immediately causes situations of spatial climate injustice. At the same time, it also contributes to temporal climate injustice for future generations by deviating from urgent action to reduce global warming. 


\section{Authors}

Tor A. Benjaminsen is a human geographer and Professor of Environment and Development Studies at the Norwegian University of Life Sciences. He uses a broad political ecology framework in his research and teaching, which is focused on issues of environmental governance, land rights, justice, pastoralism, and agrarian and environmental change. Most of his research has taken place in the Sahel, East Africa and South Africa, as well as in Norway. He is a lead author of the 6th IPCC Assessment Report and an Associate Editor of Political Geography.

Hanne Svarstad is a sociologist, political ecologist, and Professor of Development Studies at Oslo Metropolitan University (OsloMet). Her present research is about climate change mitigation, environmental and climate justice, and critical climate education. Most of her fieldwork has been conducted in Tanzania, Uganda, and Norway. For more than a decade Hanne has carried out research about the climate mitigation scheme of reducing emissions from deforestation and forest degradation (REDD+) in developing countries, with a focus on Tanzania and Norway. She is also engaged in theoretical studies of power, justice and discourses, as well as in discussions of green development approaches.

Iselin Shaw of Tordarroch recently graduated from the Norwegian University of Life Sciences with an MA in International Environmental Studies. Her dissertation is titled 'A Political Ecology of the Climate-Migration-Conflict Nexus in Syria'. Iselin has previously studied Arabic, development studies, crisis management and social anthropology. She has worked for the Norwegian Refugee Council focusing on youth agripreneurship and for the Norwegian Embassy in Amman with their political and development portfolio. She has spent several years working as a photographer and journalist, and is now with the Norwegian Football Association working on human rights and social responsibility in sports.

\section{Notes}

* Benjaminsen and Svarstad are grateful to the Research Council of Norway, which funded their writing of this article through the Greenmentality project (Grant number 250975). Shaw of Tordarroch thanks Pinar Cetinkaya and colleagues at CARE International Turkey for their support in recruiting Syrian respondents.

1 For instance, Fraser gives the example of how white male industrial workers may be unemployed through a factory closing because of a speculative corporate merger (Fraser and Honneth 2003: 35). 


\section{References}

Angelsen, A. et al. (2017) 'Learning from REDD+: A Response to Fletcher et al', Conservation Biology 31.3: 718-20

Arendt, H. (1973) The Origins of Totalitarianism, New York NY: Harcourt Brace Jovanovich

Asiyanbi, A.P. (2016) 'A Political Ecology of REDD+: Property Rights, Militarised Protectionism, and Carbonised Exclusion in Cross River', Geoforum 77: 146-56

Asiyanbi, A. and Lund, J.F. (2020) 'Policy Persistence: REDD+ Between Stabilization and Contestation', Journal of Political Ecology 27.1: 378-400

Benjaminsen, T.A. (2000) 'Conservation in the Sahel: Policies and People in Mali, 1900-1998', in V. Broch-Due and R.A. Schroeder (eds), Producing Nature and Poverty in Africa, Uppsala: Nordic Africa Institute

Benjaminsen, T.A. and Ba, B. (2021) 'Fulani-Dogon Killings in Mali: Farmer-Herder Conflicts as Insurgency and Counterinsurgency', African Security 14.1: 4-26

Benjaminsen, T.A. and Ba, B. (2019) 'Why Do Pastoralists in Mali Join Jihadist Groups? A Political Ecological Explanation', Journal of Peasant Studies 46.1: 1-20

Benjaminsen, T.A. and Hiernaux, P. (2019) 'From Desiccation to Global Climate Change: A History of the Desertification Narrative in the West African Sahel, 1900-2018', Global Environment 12.1: 206-36

Benjaminsen, T.A. and Svarstad, H. (2021) Political Ecology: A Critical Engagement with Global Environmental Issues, London: Palgrave Macmillan

Benjaminsen, T.A.; Holden, S.; Lund, C. and Sjaastad, E. (2009) 'Formalisation of Land Rights: Some Empirical Evidence from Mali, Niger and South Africa', Land Use Policy 26.1: 28-35

Bétrisey, F.; Bastiaensen, J. and Mager, C. (2018) 'Payments for Ecosystem Services and Social Justice: Using Recognition Theories to Assess the Bolivian Acuerdos Reciprocos por el Agua', Geoforum 92: 134-43

de Châtel, F. (2014) 'The Role of Drought and Climate Change in the Syrian Uprising: Untangling the Triggers of the Revolution', Middle Eastern Studies 50: 521-35

Chomba, S.; Kariuki, J.; Friis Lund, J. and Sinclair, F. (2016) 'Roots of Inequity: How the Implementation of REDD+ Reinforces Past Injustices', Land Use Policy 50: 202-13

Chu, E. and Michael, K. (2018) 'Recognition in Urban Climate Justice: Marginality and Exclusion of Migrants in Indian Cities', Environment and Urbanization 31.1: 139-56

Daoudy, M. (2020) The Origins of the Syrian Conflict: Climate Change and Human Security, New York NY: Cambridge University Press

Fraser, J.A. (2018) 'Amazonian Struggles for Recognition', Transactions of the Institute of British Geographers 43.4: 718-32 Fraser, N. (2009) Scales of Justice: Reimagining Political Space in a Globalizing World, New York NY: Columbia University Press 
Fraser, N. (2000) 'Rethinking Recognition', New Left Review 3.3: 107-18

Fraser, N. (1999) 'Social Justice in the Age of Identity Politics: Redistribution, Recognition, and Participation', in L. Ray and A. Sayer (eds), Culture and Economy after the Cultural Turn, London: SAGE

Fraser, N. and Honneth, A. (2003) Redistribution or Recognition? A Political-Philosophical Exchange, London: Verso

Gautier, D.; Benjaminsen, T.A.; Gazull, L. and Antona, M. (2013) 'Neoliberal Forest Reform in Mali: Adverse Effects of a World Bank "Success"', Society and Natural Resources 26.6: 702-16

Gleick, P.H. (2017) 'Climate, Water, and Conflict: Commentary on Selby et al. 2017', Political Geography 60: 248-50

Gleick, P.H. (2014) 'Water, Drought, Climate Change, and Conflict in Syria', Weather, Climate, and Society 6.3: 331-40

Great Green Wall (2021) (accessed 15 October 2021)

Honneth, A. (1995) The Struggle for Recognition: The Moral Grammar of Social Conflicts, trans. by J. Anderson, Cambridge MA: MIT Press

Hordequin, M. (2016) 'Justice, Recognition and Climate Change', in C.J. Preston (ed.), Climate Justice and Geoengineering: Ethics and Policy in the Atmospheric Antropocene, London: Rowman $\&$ Littlefield

Kelley, C.P.; Mohtadi, S.; Cane, M.A.; Seager, R. and Kushnir, Y. (2015) 'Climate Change in the Fertile Crescent and Implications of the Recent Syrian Drought', Proceedings of the National Academy of Sciences 112.11: 3241-46

Kortetmäki, T. (2016) 'Reframing Climate Justice: A ThreeDimensional View on Just Climate Negotiations', Ethics, Policy and Environment 19.3: 320-34

Krause, T.; Collen, W. and Nicholas, K.A. (2013) 'Evaluating Safeguards in a Conservation Incentive Program: Participation, Consent, and Benefit Sharing in Indigenous Communities of the Ecuadorian Amazon', Ecology and Society 18.4: 1

Magrin, G. and Mugelé, R. (2020) 'La boucle de l'Anthropocène au Sahel : nature et sociétés face aux grands projets environnementaux (Grande Muraille Verte, Sauvegarde du lac Tchad)', Belgeo 2020.3

Martin, A. et al. (2016) 'Justice and Conservation: The Need to Incorporate Recognition', Biological Conservation 197: 254-61

Mugelé, R. (2018) 'La Grande muraille verte: géographie d'une utopie environnementale au Sahel', PhD dissertation, Université Paris 1 Panthéon-Sorbonne

Mung'ong'o, C.G. et al. (2011) Establishing Baseline Conditions in the Kolo Hills Forests and Adjacent Communities: A Final Draft Socio-Economic Baseline Survey Report, Dar es Salaam: African Wildlife Foundation

Norwegian Ministry of Foreign Affairs and AWF (2009) Contract Between the Norwegian Ministry of Foreign Affairs (MFA) and the African Wildlife Foundation Regarding Advancing Reduced Emissions from Deforestation and Forest Degradation (REDD) in the Kolo Hills Forests (ARKFor) 
Pasgaard, M. and Chea, L. (2013) 'Double Inequity? The Social Dimensions of Deforestation and Forest Protection in Local Communities in Northern Cambodia', Austrian Journal of South-East Asian Studies 6.2: 330-55

Pellow, D.N. (2002) Garbage Wars: The Struggle for Environmental Justice in Chicago, Cambridge MA: MIT Press

Preston, C. and Carr, W. (2018) 'Recognitional Justice, Climate Engineering, and the Care Approach', Ethics, Policy and Environment 21.3: 308-23

Pulido, L. (1996) Environmentalism and Economic Justice. Two Chicano Struggles in the Southwest, Tucson AZ: University of Arizona Press

Rawls, J. (1971) A Theory of Justice, Cambridge MA: Harvard University Press

Ribot, J. (2001) Science, Use Rights and Exclusion: A History of Forestry in Francophone West Africa, London: International Institute for Environment and Development

Royal Norwegian Embassy (2014) Payment for Preservation of Forests, Dar es Salaam: Royal Norwegian Embassy

Royal Norwegian Embassy (2012) Norway and Tanzania: Partners in Development, Dar es Salaam: Royal Norwegian Embassy

Schlosberg, D. (2003) 'The Justice of Environmental Justice: Reconciling Equity, Recognition, and Participation in a Political Movement', in A. Light and A. de-Shalit (eds), Moral and Political Reasoning in Environmental Practice, Cambridge MA: MIT Press

Selby, J. (2018) 'Climate Change and the Syrian Civil War, Part II: The Jazira's Agrarian Crisis', Geoforum 101: 260-74

Selby, J.; Dahi, O.S.; Fröhlich, C. and Hulme, M. (2017) 'Climate Change and the Syrian Civil War Revisited', Political Geography 60: 232-44

Shaw of Tordarroch, I.K. (2021) 'A Political Ecology of the ClimateMigration-Conflict Nexus in Syria', Master's dissertation, Faculty of Landscape and Society, Norwegian University of Life Sciences

Svarstad, H. (2021) 'Critical Climate Education: Studying Climate Justice in Time and Space', International Studies in Sociology of Education 30.1-2: 214-32

Svarstad, H. and Benjaminsen, T.A. (2020) 'Reading Radical Environmental Justice through a Political Ecology Lens', Geoforum 108: 1-11

Svarstad, H. and Benjaminsen, T.A. (2017) 'Nothing Succeeds like Success Narratives: A Case of Conservation and Development in the Time of REDD', Journal of Eastern African Studies 11.3: 482-505

Thébaud, B. and Batterbury, S. (2001) 'Sahel Pastoralists: Opportunism, Struggle, Conflict and Negotiation. A Case Study from Eastern Niger', Global Environmental Change 11.1: 69-78

UNCCD (2020) The Great Green Wall Implementation Status and Way Ahead to 2030, Bonn: United Nations Convention to Combat Desertification (accessed 15 October 2021) 
UN-REDD Programme (2012) 'UN-REDD Programme Social and Environmental Principles and Criteria: UN-REDD Programme Eighth Policy Board Meeting', 25-26 March 2012, Asunción, Paraguay

Werrell, C.E.; Femia, F. and Sternberg, T. (2015) 'Did We See it Coming?: State Fragility, Climate Vulnerability, and the Uprisings in Syria and Egypt', SAIS Review of International Affairs 35.1: 29-46

Yeo, N.R. (2018) 'Diagnostic environnemental de la mise en œuvre du programme Grande Muraille Verte au Sénégal : Étude comparée des bases opérationnelles de Mbar Toubab, Koyli Alpha et Widou Thiengoly', Master's dissertation, AgroParisTech 